\title{
VIOLATION OF MAXIMS IN GARFIELD'S UTTERANCES IN GARFIELD COMIC STRIPS
}

\author{
Grace Sonia Simarmata $^{1}$, Umar Mono ${ }^{2}$, Ely Hayati Nasution ${ }^{3}$ \\ Universitas Sumatera Utara ${ }^{1,2,3}$ \\ gracesoniasimarmata@mail.com
}

\begin{abstract}
This thesis focuses on types of maxims violated, how the maxims are violated, and the reasons of the violation of maxims that arise from conversations in Garfield comic strips in which Garfield engages due to Garfield's utterances are used as the data to be analyzed, using Grice's theory. This study uses descriptive qualitative method as the research method because the data are not numerical data in forms of utterances in comic strips. This study aims to answer problems which are what types of maxims are violated, how maxims are violated, and the reason of the violation of maxims. The objectives are to find out what maxims are violated in Garfield's utterances, describe how the maxims are violated, and to find out the reason of why Garfield violates the maxims in Garfield comic strips. 15 comic strips that are divided into two regarding number of maxims violated - the violation of one single maxim and the violation of multiple maxims-as well as 8 reasons of the violation of maxims (to save the face, avoid doing what is asked, cheer up the hearer, convince the hearer, make a fool of the hearer, abuse verbally, avoid talking, satisfy the hearer) in Garfield comic strips are found to be the result of the analysis of this study.
\end{abstract}

Keywords: Violation of Maxims; Garfield; Utterance; Comic

submit date: 31-01-2021 accept date: 27-02-2021 publish date: 13-03-2021

Correspondence author: Grace Sonia Simarmata, Universitas Sumatera Utara, Indonesia. E-Mail: gracesoniasimarmata@gmail.com

Doi: https://doi.org/10.36929/sigeh\%20elt.v1i1.336

\section{(c) (i) (2)}

Journal SIGEH licensed under a Creative Commons Attribution-ShareAlike 4.0 International License.

\section{INTRODUCTION}

Humans are known as members of society due to interacting with one another. When the interaction is found in the form of communicating particularly by using language, another level is achieved in which humans are called as members of a speech community.

To communicate, language is used. In communicating with others, thoughts, and feelings had in mind are exchanged from one person to another. Human communications are divided into two types: written and spoken communication. Spoken or oral communication can be found in the form of utterances, whereas written communication can be found in the texts and symbols.

According to Online Cambridge Dictionary, conversation is a talk between two or more people in which thoughts, feelings and ideas are expressed, questions 
are asked and answered, or news and information is exchanged. A number of people is considered important in conversing or conversation in which at least two participants are involved in it. In conversing, there must be found at least two people exchanging information as thoughts, ideas, or feelings needed to be expressed.

In order to make a conversation happen, cooperativeness has to be shown by speaker and listener as members of a speech community. The same interest in something is shared between speaker and listener and talked over it as utterance is exchanged as the proof of cooperativeness. Many of us are often found not aware of this at the time of doing it.

Famous cat comic strip entitled Garfield is used as object of analysis due to some reasons: the genre of the comic which is comedy and the character itself on which the comic is revolved around. In most of comics, film, or comedy show, it is found commonly if not the verbose character, the character tends to use very limited words due to either to be sarcastic to create humor or too lazy to interact. Thus, chance for those characters to violate maxims is found higher. Information uttered by Garfield in Garfield mostly is found to be insufficient, false, irrelevant, ambiguous, and ineffective. Garfield is also often found not want to cooperate in communicating due to his laziness.

In Garfield, comedy can be found in the form of joke used to entertain readers. In joking, people tend to mislead or misunderstanding communication or information to make people laugh. People who do joking make a fool of themselves or someone else by misunderstanding something on purpose, so there will be something for readers to laugh at. In Garfield, uncooperativeness can be found as Garfield does not respond or act as what is expected by his interlocutor simply just not do anything. Garfield likes to make a joke about lasagna, Jon, Odie, or basically anything that comes to his mind. Humor in Garfield the cat comic strip has achieved its goal which is to make people burst of laughter and smile (Ross, 2005:1).

To research violation of maxims is to understand that it is considered important to know the fact that maxims sometimes are violated in a conversation 
as readers or hearer might find themselves not realize the phenomenon especially while reading Garfield comic strips and that information is needed by the time speaking effectively is needed. In addition to that, research regarding violation of maxims has been numerously conducted by many researchers mostly in terms of speeches spoken by public figures either political or nonpolitical public figure such as interview, speech, etc. However, the written data especially on comic has not that many been analyzed.

Similar previous study that applied Grice's four maxims theory: Arthanti (2013) does a comparative research in which she compared violation of maxims found in source text and target text of "Hangs Out" Garfield comic. The types of maxim violations done by all characters in the comic book are put into classification. Two problems of study are found: (1) what maxim is violated in source text in Garfield "Hangs Out" Comic and (2) whether violation of maxim can also be found in the target text. Grice's four conversational maxims theory is used as the theory to analyze this study as well. However, translation analysis is involved as the study is focused on determining the process of translating source text into target text has effect on eliminating violation of maxims or not. Violation of maxims in the original text of the comic is not only the thing to analyze as violation of maxims in target text (text in Indonesian language) and explaining the process of how violation of maxims in source text can be found or not be found in target text regarding to the effect of translation process are needed to answer. Therefore, translation theory is included in her study.

The source of data between this study and her study are different due to Arthanti's data is taken from Garfield "Hangs Out" comic book and her research 
was done in 2013 meaning Garfield comic strips that were released on or before 2013 are the ones used. This study is showed to contribute in terms of giving more examples of violation of maxims occuring in Garfield comic book meaning the violation of maxims done by Garfield the cat itself can be found as well as providing insight into the personality of Garfield from his utterances.

Two problems of study in Pribadi (2018) article journal are found in which he conducts a research about violating maxims as the humorous sense in a movie: (1) what maxims are violated in the movie Deadpool and (2) how does the violation of maxim create the humorous sense in the movie Deadpool. Some characteristics of his research are found similar to this study: (1) using Grice's four maxims of conversation, (2) descriptive qualitative approach as research design, and (3) documentation method for the technique of data collection. Differences between his study and this study are found as follows: (1) the data was taken from a movie meanwhile the data in this study is taken from comic strips on website and (2) the method of collecting data. This study is showed to contribute in terms of giving a deep insight into other possibilities or examples of conversation that contain violation of maxims.

Violation of maxims done by Dodit Mulyanto in Stand-Up Comedy Indonesia season 4, which is a televised Indonesian comedy show competition in which candidates perform comedy in live and in front of audience while standing up, are analyzed by Raharja and Rosyidha (2019). Raharja and Rosyidha's study is aimed to get types of violation of maxims, the most dominant one, and the reason behind the most dominant. Three research problems are found as follows: (1) what maxims from cooperative principle are violated by Dodit Mulyanto, (2) what the most dominant maxim is violated, and (3) what is the reason behind the most dominant maxim violation. This study is showed to contribute in terms of giving insight about possible factors that can be the reasons underlying the act of violating maxims.

Some differences between their study and this study are found. Percentage of four violation maxims is involved in their study unlike in this study. Besides, the source of data and the steps of collecting data are found to be different. The 
translated source text is attached to present both data in source text and target text. In addition to the differences, checklist instrument is used meanwhile the same instrument is not used in this study instead of documentation technique in which transcript technique is applied alongside note-taking. Furthermore, qualitative method is used which is different from this study in which descriptive qualitative method is used. This study is showed to contribute in terms of giving more examples of the violation of maxims.

Non-observance of Grice's maxims in a drama script was analyzed once by Triyatun (2013). Two research problems in the article can be concluded from the objectives of the study: (1) what types of non-observance maxims can be found in the Death of the Salesman Drama Script by Arthur Miller and (2) what is the intention behind non-observance maxims that occur? Differences between her research and this research are found as follows: (1) All non-observance maxims that occur are listed and analyzed meanwhile this study is only focused on violation of maxim. Different objectives of study in her study compared to this study are caused by difference scopes of study as not only violation of maxims can be found. (2) Triyatun's data is taken from drama script meanwhile the data in this study is taken from comic strips. It is also found that the way of collecting data is different unlike in this study, comic strip images are provided. Her study and this study are similar in terms of both are descriptive qualitative research in which the research focuses on explaining the phenomenon that occurs. This study is showed to contribute in terms of giving more examples of violation of maxims.

Non-observances of Grice's maxims in the creation of humor in a Chinese sitcom are analyzed by Xue (2017) as a dissertation submitted. The research is aimed to find out all types of non-observances of maxims considered as important key to create humor. The difference between the research and this ongoing research is found to be in the form of theory used. Grice's Non-Observances of Cooperative Principle is used in the research as the theory of analysis meaning not only the theory of violating used but the theory of flouting, infringing, opting out, and suspending maxims are also used and, being so, the number of theory used is considered more in terms of number. Difference in the scope of study is caused 
by difference in theory used between this research and the ongoing research. This study is showed to contribute in terms of a helpful reference to all types of nonobservances maxims.

Referring to the objectives and scope of the study, this study theoretically is expected to give contribution in pragmatic field, especially about violation of maxims in the way that those who are interested, whether for the sake of learning or teaching, can get linguistic knowledge about the phenomenon of the violation of maxims. Practically, this study is expected to give benefit in terms of being additional reference that can be used either by the students or readers in general who wants to conduct a research under the same topic. In addition to that, this study can be implemented in order to make an effective communication if given limited time to speak as the examples of the phenomenon of violation of maxims.

\section{METHOD}

Qualitative approach is used as this study is focused on descriptive forms in doing the analysis. The result of this study is expected to be in descriptive forms. For the research method, descriptive method is used. Descriptive method is found to suit the objective of study in which the data will be described and interpreted, the process of how maxims are violated and found in Garfield's utterances will be explained, and explanation about the reasons behind violation of maxims done by Garfield are provided in words. In other words, descriptive qualitative method is used as the research method in this study due to reasons such as this study aims to provide information or meaning from the social phenomenon in descriptive forms in the way of describing the way violation of maxims occur and the reasons behind it.

The data are clauses, sentences, phrases, or words which are in the forms of utterances especially uttered by Garfield in Garfield comic strips as well as utterances which give indication to the violation of maxims. Clauses, sentences, phrases, or words from other characters will also be included. However, it is only to give a complete description of what is going on, accompanies Garfield's utterances, and proves that Garfield's utterances point out the act of violating of maxims. The data are taken from Garfield's utterances in Garfield comic strips 
from July $1^{\text {st }} 2019$ - Dec $31^{\text {st }} 2019$ on www.gocomics.com/Garfield. Documentation and note-taking are used as the data collection procedures. The steps of collecting data will be done as follows:

1. Reading Garfield comic strips from June $1^{\text {st }}$ until December $31^{\text {st }} 2019$ on gocomic website comprehensively for the purpose of understanding each situation in each comic strip deeply. Gocomic website was chosen because in that website Jim Davis, the creator of Garfield, publishes Garfield comic strip regularly every day meaning Garfield comic strips can be found on that site. Moreover, the website is easy and free to access.

2. Collecting words, phrases, clauses, or sentences that contain violation of maxims.

3. Documenting each comic strip as the images of the comic strips that indicate violation of maxims are presented by simply taking screenshots of them all.

4. Writing down the transcription of each selected Garfield comic strip. The transcript is expected to contain not only dialogue between the characters, but also the nonverbal data such as facial expressions, intonation and so on to show the context and situation. In this stage, some notes are taken and words, phrases, clauses, or sentences that indicate violation of maxims are marked in bold.

5. Classifying what maxims are violated in Garfield comic strips from July $1^{\text {st }}$ until December $31^{\text {st }} 2019$.

In analyzing the data, the writer use interactive model proposed by Miles, Huberman, and Saldana with three steps; data condensation, data display, and conclusion: drawing and verification (2014).

\section{RESULT AND DISCUSSION}

\section{Discussion}




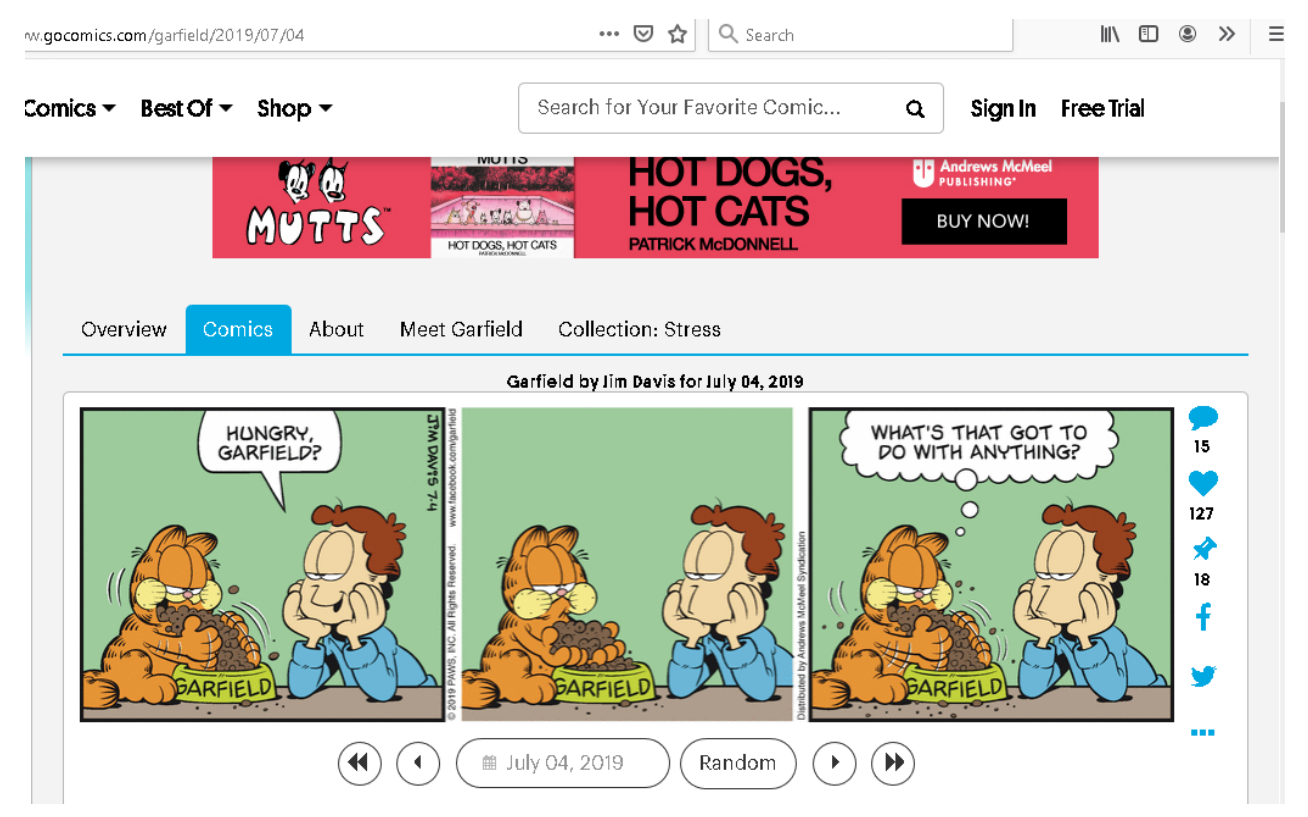

Figure 4.1.1 Garfield for July $04^{\text {th }} 2019$

\section{Datum 1}

Characters

Background

\section{: Garfield for July $04^{\text {th }} 2019$}

: Garfield and Jon

middle of eating as catching Garfield eating so fast.

Jon

: "Hungry, Garfield?"

\section{Garfield}

\section{: "What's that got to do with anything?"}

\section{Violation of maxims: Quantity}

Violation of maxim of quantity is illustrated in the above conversation. In the conversation, it can be showed that Jon's wish is to get certain information regarding whether Garfield is really that hungry as it can be seen as Garfield keeps putting massive amount of food in his mouth. To get the answer 'yes' or 'no' is expected by Jon for catching Garfield in the act of massive eating. Jon's question can be simply understood as yes or no question meaning the answer 'yes' or 'no' is the only thing required. The response given by Garfield can be regarded as not meeting the information that is required or needed by Jon. Jon is left out unsatisfied and Garfield can be seen not to the point or go straight answering Jon's question.

The act of violating maxim of quantity done by Garfield in the above talk exchange can be measured from the type of response given, the circumstance and 
the tone expressed. Garfield saying 'What's that got to do with anything?' is uttered along with annoyed facial expression and tone of voice meaning the act of violating maxim of quantity is chosen that way as the result of getting annoyed by Jon for disturbing Garfield's having his meal. The reason of violating the maxim can be said as Garfield's effort to save his face as the saying 'what's that got to do with anything?' is uttered if someone says something that is offended or annoying.

\section{Garfield by Jim Davis for July 19, 2019}
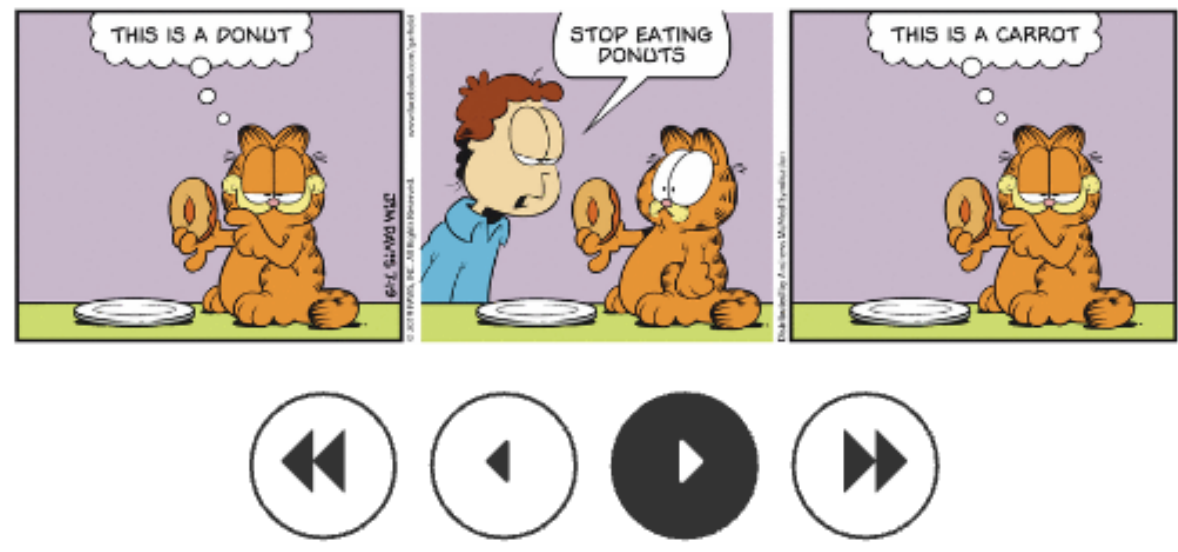

Figure 4.1.2 Garfield for July $19^{\text {th }} 2019$

\section{Datum 2}

: Garfield for July $19^{\text {th }} 2019$

Characters

: Garfield and Jon

Background: At home. While holding donut, Garfield tells the audience what he's holding. Jon comes and warns Garfield to stop eating it. Garfield does a fast correction of his saying by telling what he's holding is a carrot.
Garfield
:"This is a donut."
Jon
: "Stop eating donut."
Garfield : "This is a carrot."

\section{Violation of maxims: Quality and Quantity}

Garfield is expected to participate in the contribution of giving the right amount of information as is required by the other participant, Jon. The response given by Garfield to the request for him to stop eating donut is not considered 
informative as the saying 'this is carrot' is said to not have something to do with Jon's question. The answer like 'alright' as the example of obeying the request or 'I do not want' as the example of refusing the request is required from that kind of question.

Participant in a conversation is required to contribute in the way of giving information that contains true sayings or things that is believed to be true according to them in order to fulfill maxim of quality. Violation of maxim of quality obviously can be seen from the above ongoing conversation judging from the way maxim of quality is not obeyed by Garfield. The fact is denied by Garfield while holding a donut and not the carrot, yet misleading the audience is chosen by Garfield by saying what is believed to be false in terms of lying. Misleading audience on purpose and saying the opposite of things that already can be seen its evidence are considered as the act of breaking maxim of quality in terms of violation.

The violation of maxim of quality is done by Garfield in order to avoid doing what is asked due to the request is not what is wanted. This could be seen when Jon told Garfield to stop eating donuts, the words of Garfield's saying is corrected by Garfield himself.

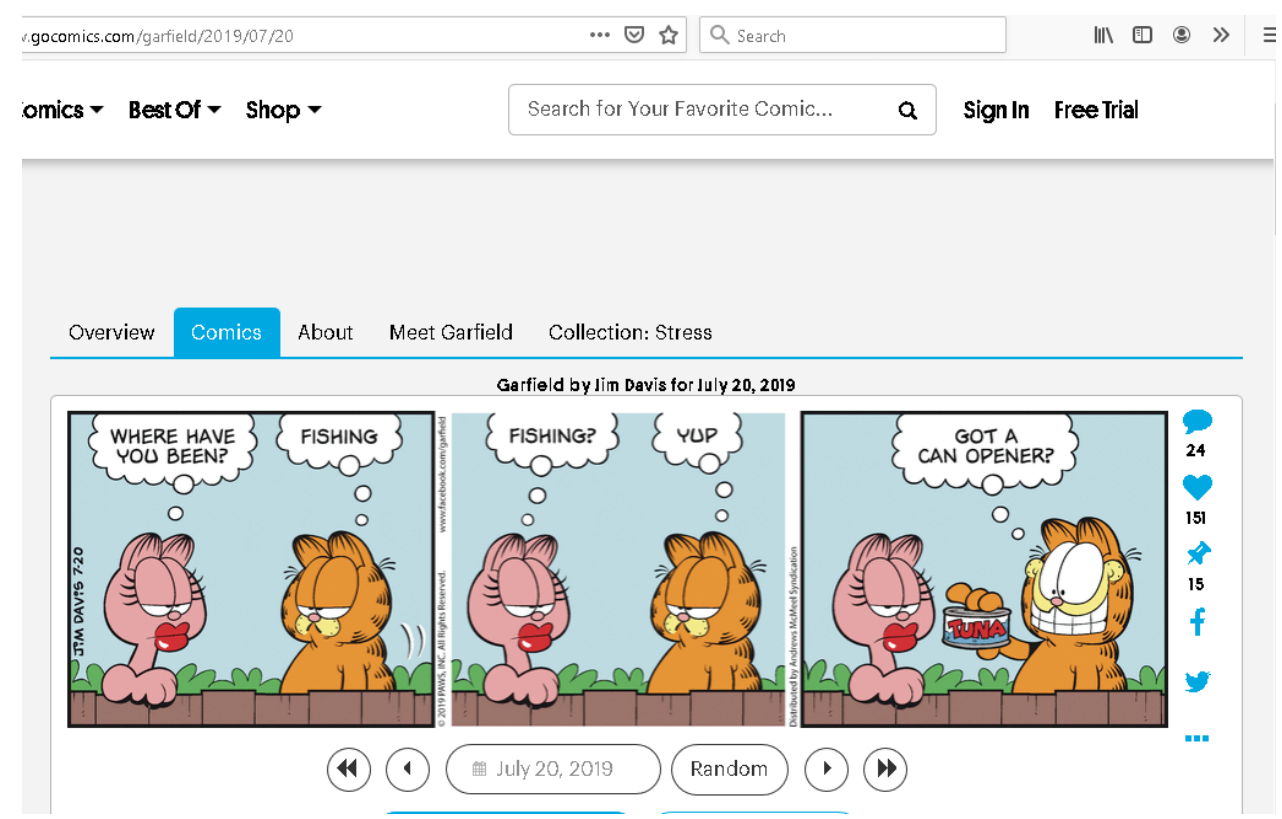

Figure 4.1.3 Garfield for July $20^{\text {th }} 2019$ 


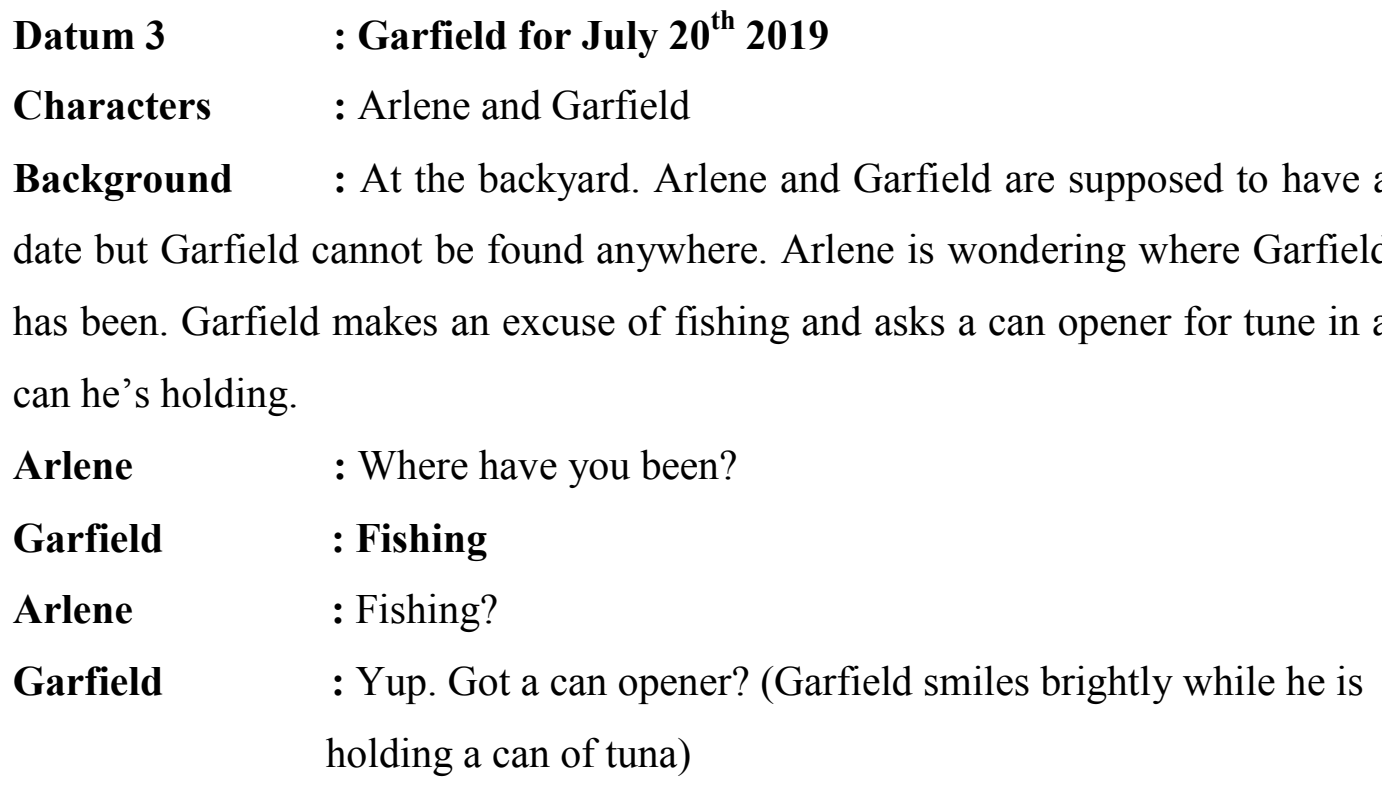

\section{Violation of maxim: Quality}

From that conversation, maxim of quality is violated by Garfield. Judging from the context situation, Garfield's contribution is understood as uncooperative contribution in terms of not saying something that is truthful. When Arlene says 'Where have you been?' the only information is needed is what was Garfield doing. The answer given by Garfield can be measured and said to meet conversation maxims of quantity and relevant. It is proven in the way that observing only the maxim of quantity can already be fulfilled by one word 'fishing' without Garfield feeling the needs to add more information. However, a true information is not reflected by the word 'fishing' meaning Garfield does not really do fishing due to the fish meant for Garfield to catch is referred to the canned fish. Thus, the above ongoing conversation is considered as the act of Garfield not follow maxim of quality by saying something that is known to be false. In other word, Garfield's utterance is known as a lie and misleading on purpose.

The violation of maxim of quality above is done because saving his face in front of his cat girlfriend is said to be what is wanted by Garfield. The thing is to look like hard working cat in getting food. In the end, to keep and present his lying with a smile on his face as well as let Arlene sees the true yet contradicted condition are wanted by Garfield . 


\section{Garfield by Jim Davis for September 12, 2019}
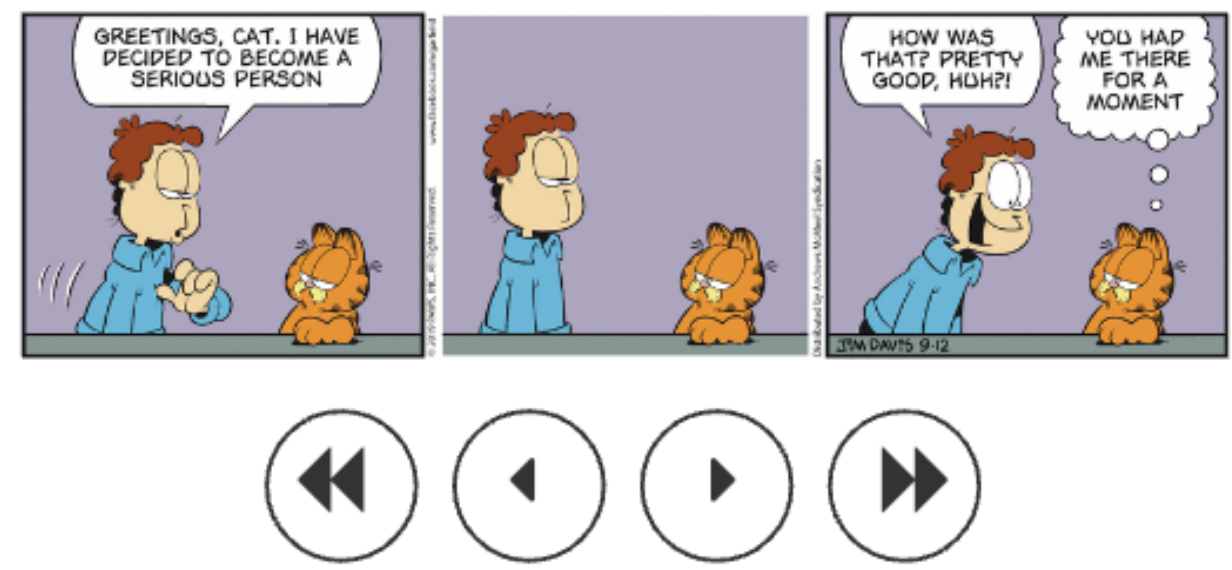

Figure 4.1.4 Garfield for September $12^{\text {th }} 2019$

\section{Datum 4}

: Garfield for September $12^{\text {th }} 2019$

Characters

: Jon and Garfield

Background : Jon comes to Garfield and speaks with a serious tone and look telling Garfield that he has decided to become a serious person, but suddenly speaking in a burst of emotion as the serious atmosphere going away. Garfield does no reaction with the typical of uninterested look on his face.

Jon

: "Greetings, Cat, I have decided to become a serious person."

Garfield : “.."

Jon

: "How was that? Pretty good, huh?"

Garfield : "You had me there for a moment."

\section{Violation of maxims: Quality}

Maxim of quality is violated openly in the above talk exchange as it is not obeyed by one of interlocutors. It is considered a must to speak only what is believed to be true information or at least information which contains evidence in it by interlocutor. Not following it is considered as the act of breaking maxim of quality. The case of irony is illustrated in the above comic strip. The violation of maxim of quality is found to be in the form of ironic comment as Garfield's saying is not supposed to be in contrast to what actually is felt if observing maxim of quality is wanted to be fulfilled. The saying 'you had me there for a moment' is 
not really meant by Garfield. The response given by Garfield is considered to contradict the fact that Jon's prank does not surprise him at all.

The reason behind the violation above is believed due to cheer up the other participant. Garfield who is seen to say 'you had me there for a moment' is said to be the way of cheering Jon up by pretending like Garfield is tricked.

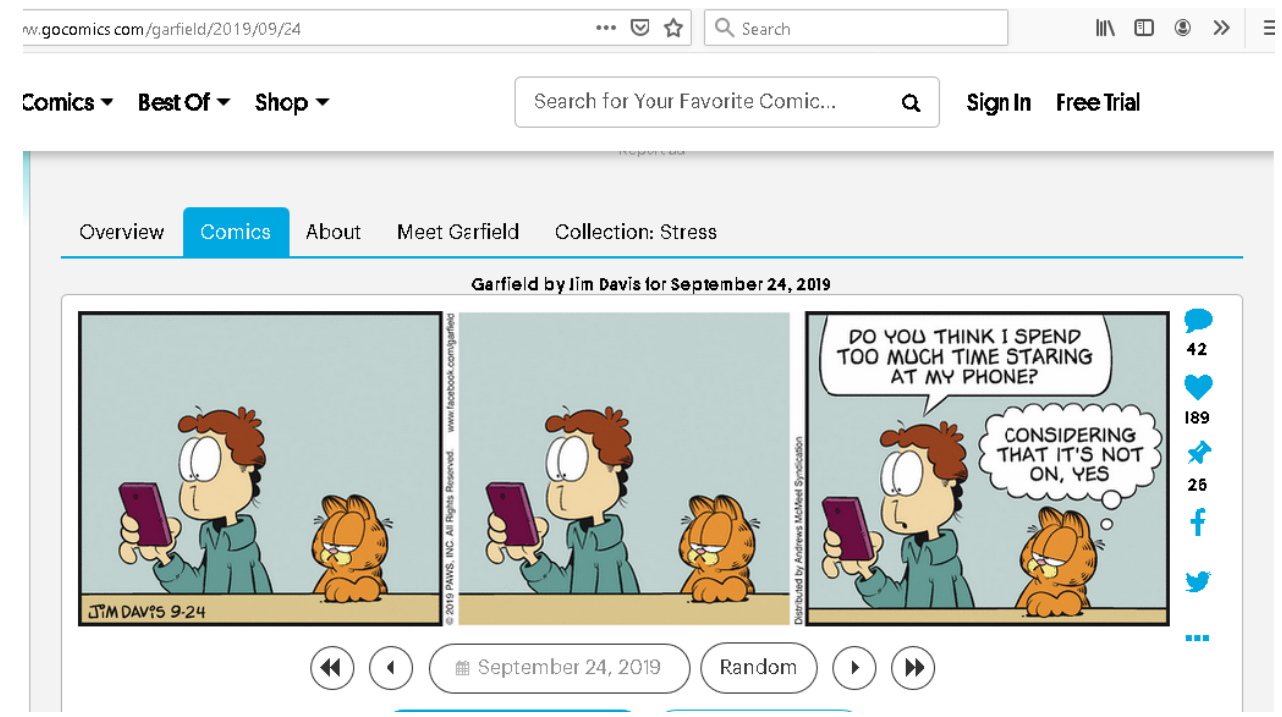

Figure 4.1.5 Garfield for September $24^{\text {th }} 2019$

\section{Datum 5 : Garfield for September $24^{\text {th }} 2019$}

Characters : Jon and Garfield

Background : Jon asks Garfield whether he spends too much time staring at his phone.

Jon

Garfield

\section{Violation of maxim: Quantity}

Maxim of quantity is violated in the above talk exchange. The contribution given by Garfield that comes in the form of responding saying 'considering that it's not on, yes' is considered in requirement in terms of the quantity or how much of the information. However, the contribution is said to be over of how much is needed and asked by Jon. The maxim of quantity is broken as it is considered a must to be cooperative in the way of giving not too little or too much information. The clause 'considering that it's not on' is not asked by Jon. The word 'yes' or 'no' is actually the only answer needed. 
By violating maxim, to satisfy the hearer which is Jon is wanted by Garfield. Talking too much information in the above conversation is concerned as the effort to convince Jon without doubt and to make Jon believe what he said as the word 'yes' is considered not enough by Garfield to convince the other that causes maxim of quantity violated.

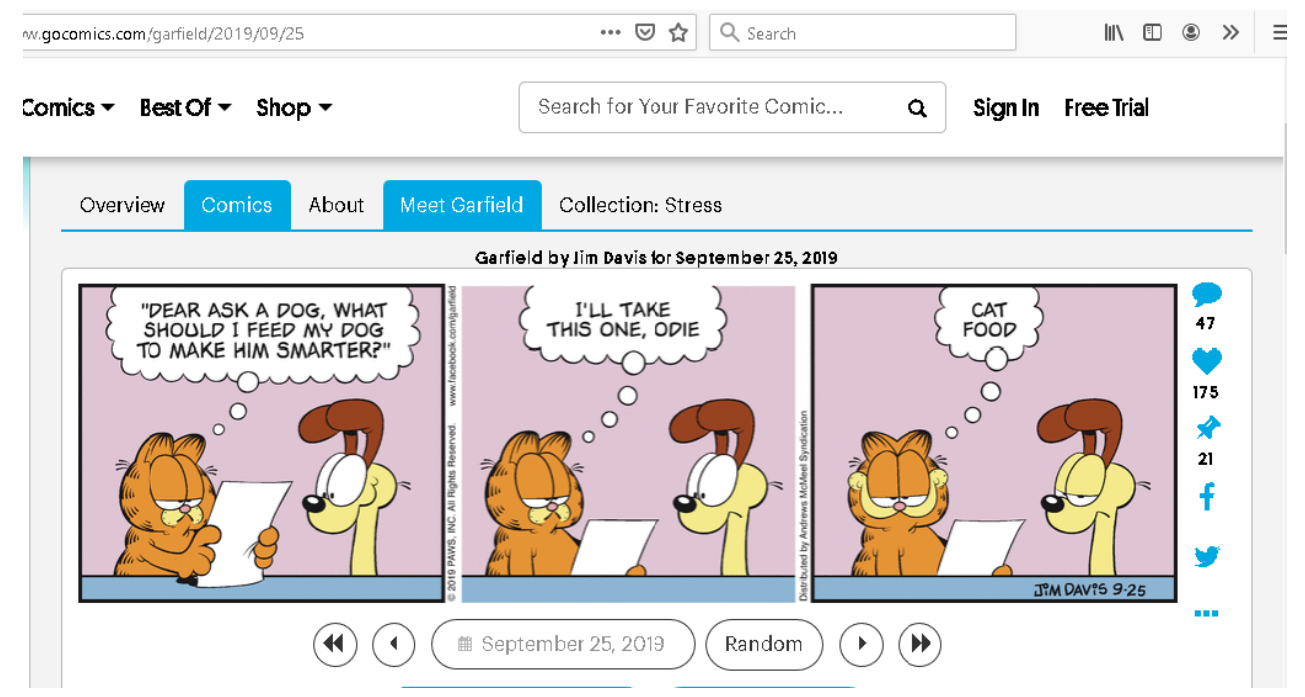

Figure 4.1.6 Garfield for September $25^{\text {th }} 2019$

\section{Datum 6 : Garfield for September $25^{\text {th }} 2019$}

\section{Characters : Garfield and Odie}

Background : Garfield and Odie read letter from audience. It is a letter for Odie this time.

Garfield : : "'Dear ask a dog, what should I feed my dog to make him smarter?' I'll take this one, Odie."

\section{Odie $\quad: \ldots$}

\section{Garfield : "Cat food."}

Odie : “...”

\section{Violation of maxims: Quality}

The violation of maxim of quality as what is illustrated in the above conversation is caused by the absence of truthfulness information as the way to contribute to follow cooperative principle. Garfield's response saying 'cat food' does not meet the truthfulness needed in a conversation. Something is known to be false by Garfield, but it is still given and kept being delivered by Garfield itself. 
Logically, cat food is not consumed by dog. Therefore, Garfield's response is considered a lie and misleading. No evidence is found to say that cat food is what someone should feed their dog with. In other words, the contribution is made as required in the state of giving the right amount information, relevant information, and in not ambiguous way, yet the contribution is considered not true causing the violation of maxim of quality.

The violation maxim of quality in the above example is done by Garfield in order to deceive someone (audience) as the saying itself is said to mislead anyone easily. Cat food is known to be food that is supposed to be given to cat and not dog in order to make a dog smarter.

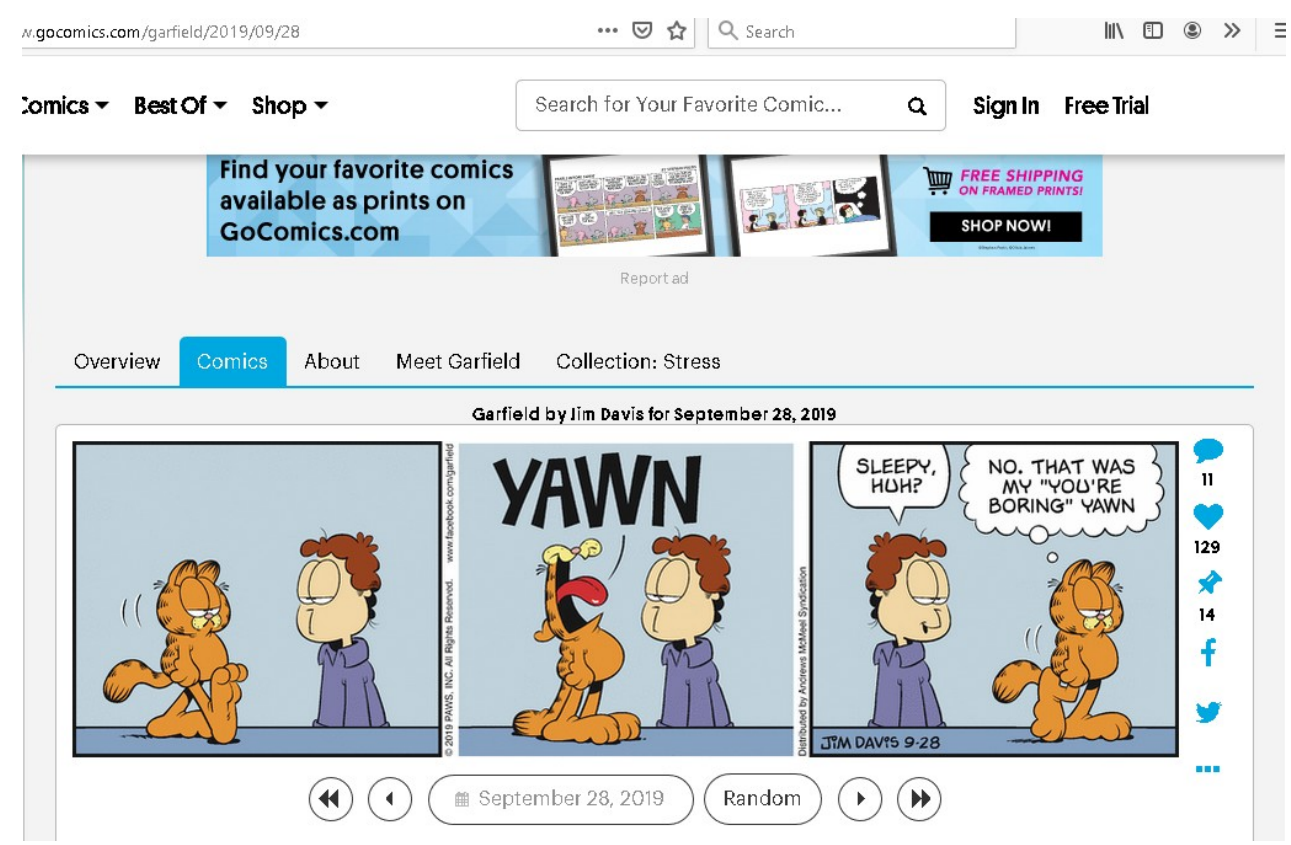

Figure 4.1.7 Garfield for September $25^{\text {th }} 2019$

Datum 7 : Garfield for September $25^{\text {th }} 2019$

Characters : Garfield and Jon

Background : Garfield encounters Jon on his way and yawning.

Jon : "Sleepy, huh?"

Garfield : : "No. That was my 'you're so boring' yawn."

\section{Violation of maxims: Quality and Quantity}

Violating maxim of quality is said to be the time or case when speaker does not contribute in a conversational talk exchange in the way of giving true 
contribution. The true contribution is measured from the sayings or responses that come in the form of true information to get the purpose of the talk exchange. Giving untruthful contribution is considered to be the cause of breaking maxim of quality as the aim of the talk cannot be gained due to the participant is not trustworthy. In the stage of maxim of quantity, contribution can be said failed to fulfill conversational principle if excessive or less information is given. Being excessive in saying things can also be said as not going straight to the point of discussion and causing the act of not observing maxim of quantity like in the above example.

Garfield's response 'no' is considered already as is required if compared to Jon's saying. However, the need to talk more is still appeared causing the maxim of quantity is broken by saying 'that was my you're so boring yawn'.

Garfield is also found to violate maxim of quality in his saying by giving untrue information. The yawning is usually known as and triggered by sleepiness or fatigue. Choosing to add more in his saying by telling untruthfulness that the cause of his yawning is caused by seeing Jon who is just so boring there even though in fact, Jon does not do anything wrong at all or boring things. Jon is seen to only greet Garfield by asking rhetorical question 'sleepy, huh?' In other words, Garfield's participation cannot be said to meet the conversational contribution due to the contribution is not the truth or telling the true condition.

Violating maxim of quantity and quality by Garfield is done to abuse someone (Jon) verbally as the phrase 'that was my 'you're so boring' yawn' is said to be one of verbal abuses. In other words, the maxim of quantity and quality are violated, so that the attacking Jon verbally can be done and the verbal abuse itself can be delivered. 


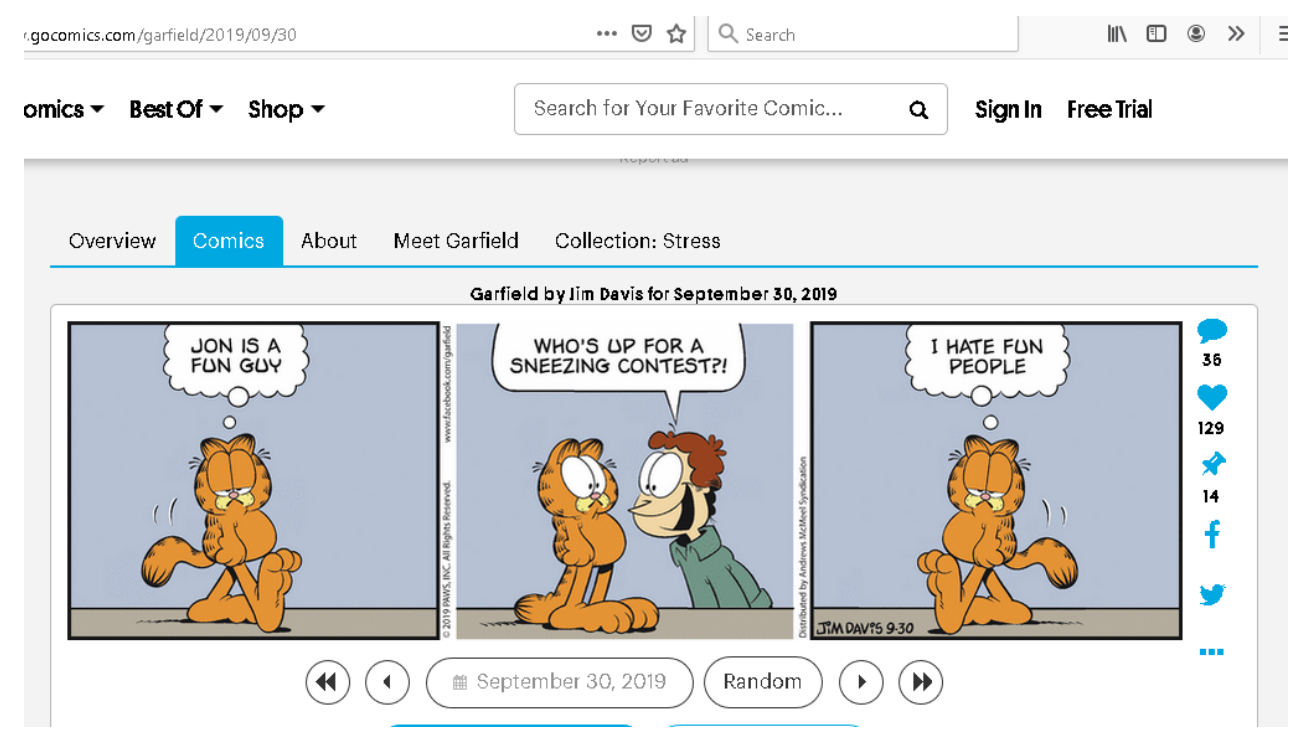

Figure 4.1.8 Garfield for September $30^{\text {th }} 2019$

Datum 8

: Garfield for September $30^{\text {th }} 2019$

Characters : Garfield and Jon

Background : Garfield says that Jon is a fun guy and adds more to his

saying that Garfield hates fun people after Jon asking him who is up for a sneezing contest.

\section{Garfield : "Jon is a fun Guy." \\ Jon : "Who's up for a sneezing contest?" \\ Garfield : :I hate fun people." \\ Violation of maxims: Quantity and Relation}

Maxim of quantity is violated by Garfield in the above conversation. The contribution given by Garfield cannot be said to meet the requirement of what should conversational contribution should be in terms of the quantity of the information. In other words, Garfield's response is not counted to answer Jon's question at all. The amount information that is needed by Jon is the answer 'yes' or 'no' regarding who is up for a sneezing contest that Jon is so passionate to join. The saying can be measured its uncooperativeness due to contribution given less excessively. The effect of being not informative can be seen as the communication cannot run well and effectively proven by Jon being left unsatisfied and the answer left unanswered. Therefore, maxim of quantity is broken by Garfield's uncooperativeness in terms of being not informative. 
Instead of answering Jon's question or contributing to fulfill maxim of relation, the response 'I hate fun people' is said to be irrelevant to the topic discussion or in this case it is a question that is being asked by Jon. No correlation is found in the response 'I hate fun people' with Jon's question 'who's up for a sneezing contest?'

The reason of the violating maxim of quantity and relation done by Garfield is seen as the way to avoid talking with someone. In the above conversation, Garfield obviously can be said avoiding Jon as the opposite direction is taken by Garfield after hearing other weirdness from Jon as well as the proper response is not given by Garfield.

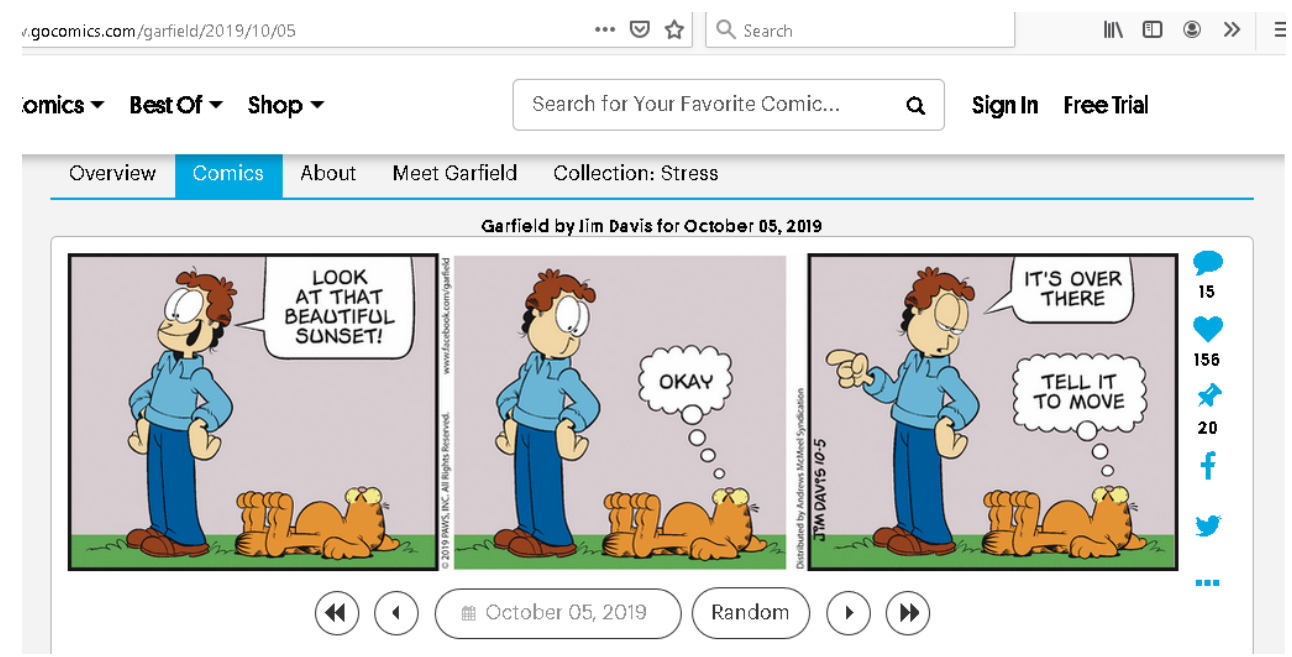

Figure 4.1.9 Garfield for October $05^{\text {th }} 2019$

Datum 9

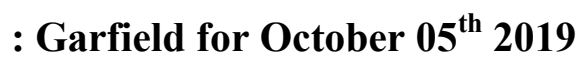

Characters

: Jon and Garfield

Background: At the front yard or the inside of the house. Garfield is lying down when Jon asks him to look at the beautiful sunset. Garfield remains in his spot and not moving even though Garfield has said 'okay'.

Jon

Garfield

Jon

Garfield

Violation of maxims: Quality

\section{: "Okay."}

: "Look at that beautiful sunset!"

: "It's over there."

: "Tell it to move." 
Violation of maxim of quality is demonstrated in the above conversation in the sense that the response or saying from Garfield is not seen truthful compared to the saying itself. The message in the response 'Okay' cannot be said to match the act of Garfield who still lies down and not move at all from his position. The evidence of untruthfulness is found right in front of the other's eyes (Jon) meaning the true condition is not portrayed from the saying 'okay'. In addition to that, the mismatch between response given by Garfield and what Garfield actually does is realized by Jon as the saying is emphasized more by saying 'it's over there' in the hope of getting cooperativeness from Garfield. Garfield is also found to admit his act of not moving from the excuse Garfield makes about telling the sunset to move in order to see it easily from his lying down position. Giving not true contribution as is required in the conversational contribution is considered as the act of violation in terms of maxim of quality.

The violation done by Garfield in the above conversation is done due to the effort of satisfying the speaker (Jon). Jon cannot be satisfied by that untrue response provided by Garfield. The effort from Jon of not making the question remains unanswered is already done. However, the fact that the response that is received by Jon is not a true contribution and misleading cannot be changed.

\section{Garfield by Jim Davis for October 11, 2019}
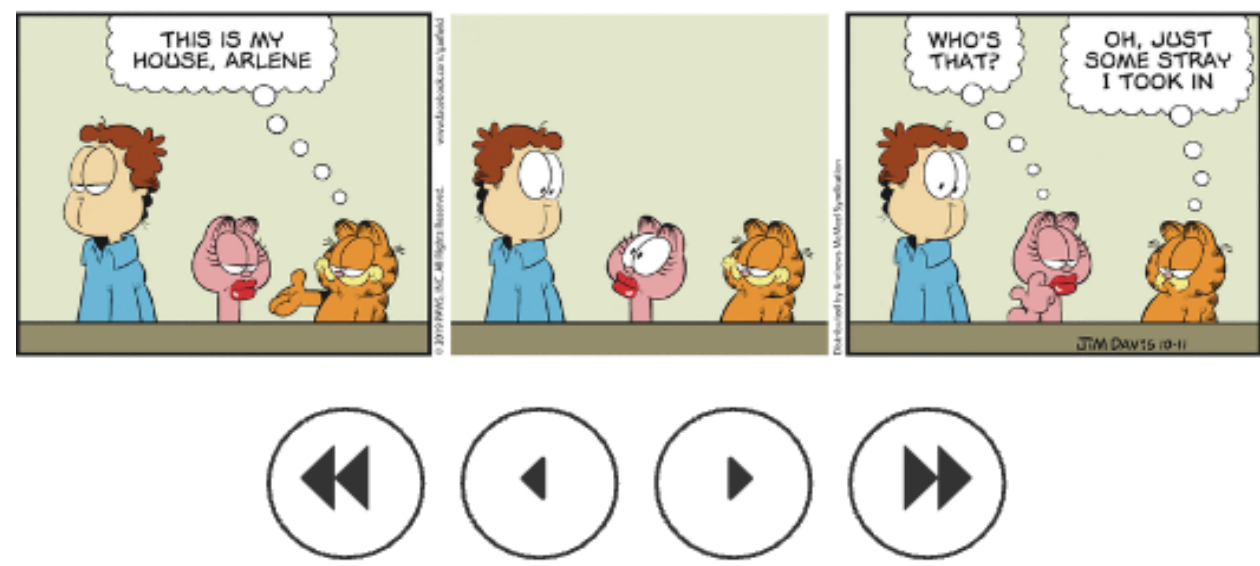

Figure 4.1.10 Garfield for October $11^{\text {th }} 2019$

Datum 10 : Garfield for October $11^{\text {th }} 2019$ 


\begin{abstract}
Characters : Arlene, Garfield, and Jon
Background : Garfield invites Arlene to his house to look around the house and tells Arlene that Jon is some stray Garfield took in. In fact, the house belongs to Jon and Garfield is just the cat owned by Jon.
\end{abstract}
Garfield : "This is my house, Arlene."
Arlene : "Who's that?"

\title{
Garfield : : “Oh, just some stray I took in."
}

\section{Violation of maxim: Quality}

The violation of maxim of quality is demonstrated in the above conversation. The time Garfield giving his response 'oh, just some stray I took in' to Arlene questioning Jon is said to be a lie. The real condition is found is that Jon is the owner of the house, but his saying is still delivered in that way causing maxim of quantity broken. The act of deceiving and giving false information is done on purpose by Garfield as the lie is delivered to Arlene quietly and without any implicature behind it. Garfield's response is said only to meet the contribution in the terms of quantity (by giving the exact amount of what is needed), relation (by giving response that is not out of topic), and manner (by not giving ambiguous language). Maxim of quality is not observed well by Garfield while delivering his saying.

The violation of maxim of quality in the above conversation is done by Garfield in order to save his face in from of his cat girlfriend, Arlene, for being a cat which owns a house. The response is chosen to be delivered in that way, so that a good face can still be had in front of Arlene. Another reason of violating maxim of quantity done by Garfield by saying 'just some stray I took in' is regarded as the effort to hide the truth. The true condition is said to be different or the opposite of what is said by Garfield. Telling false condition can be understood as the effort of hiding something that it is considered not good if told. 


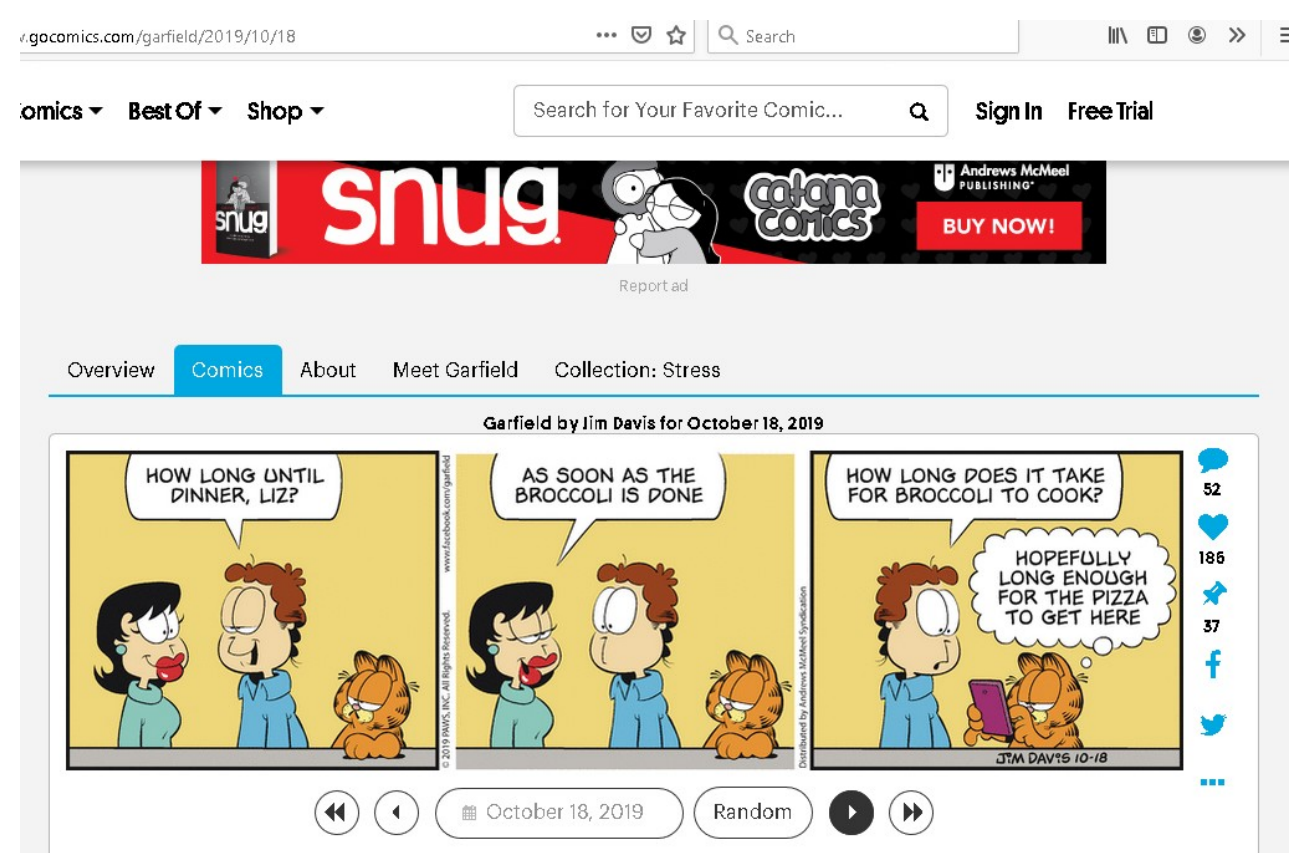

Figure 4.1.11 Garfield for October $18^{\text {th }} 2019$

\section{Datum 11 : Garfield for October $18^{\text {th }} 2019$}

Characters : Liz, Jon, and Garfield

Background : At the kitchen. The meal for dinner is still cooked when Jon asks how long until dinner time. Arlene answers by using the time for a broccoli to be done. Jon is still in confused, so Jon asks Garfield the same question. Garfield answers by saying his hope that it is not long enough for the pizza to get here.

Jon : "How long until dinner, Liz?"

Liz : "As soon as the broccoli is done."

Jon : "How long does it take for broccoli to cook?"

Garfield : "Hopefully long enough for the pizza to get here."

Violation of maxims: Quantity and Manner

Multiple violations are done by Garfield as the maxims of quantity and manner are violated at the same time when the response is delivered. Maxim of quantity is violated by Garfield because uncooperativeness is found in the saying 'hopefully long enough for the pizza to get here'. The response is said failed to fulfill the information that is required and indicated in Jon's question regarding how long for a broccoli to cook. The response is supposed to be in the right 
amount of information in order to make a conversational contribution in terms of maxim of quantity. Logically, the answer about duration of a meal to cook is said in the form of minute, hour or day. In fact, none of that right amount answers is given. The response given by Garfield can be said to be not informative because the question is left unanswered leaving Jon unsatisfied.

Maxim of manner is violated by Garfield as well. The response 'hopefully long enough for the pizza to get here' is said to be not understood easily by the other participant, Jon. Garfield's answer in the response is not informed clearly as required by the question "how long does it take for broccoli to cook?" In other words, the response is found to be difficult to understand as the response is not helpful at all in satisfying what is needed by Jon regarding knowing the duration for a broccoli to cook. Instead of saying the exact duration for a broccoli to cook that will be understood as the act of observing maxim of manner, making his contribution unclear in the saying and at risk in disobeying the maxim of manner has broken maxim of manner.

The multiple maxims are violated by Garfield in the above conversation in order to save his face and satisfy hearer. The reason is said to save Garfield face because the true condition is reflected in the last panel in which Garfield is not in focus to the topic proven by Garfield is more distracted by a food delivery app and busy in ordering a pizza delivery. Another reason of the multiple maxims violated is said to be the effort of satisfying hearer. It can be seen that Garfield is in the hope of still being able to satisfy what is needed by Jon even though maxim of manner is at the risk violated due to delivering unclear information. 


\section{Garfield by Jim Davis for November 17, 2019}
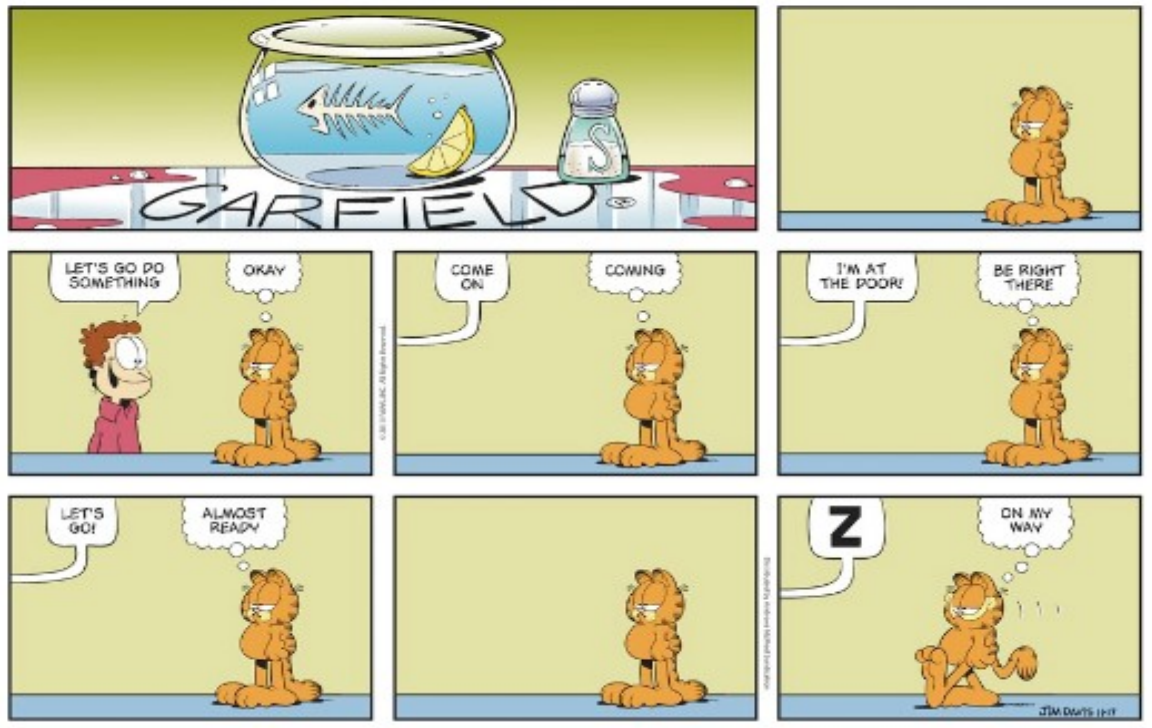

Figure 4.1.12 Garfield for November $17^{\text {th }} 2019$

Datum 12 : Garfield for November $17^{\text {th }} 2019$

Characters : Jon and Garfield

Background : Jon invites Garfield to do something and has been waiting long for Garfield to come. In fact, Garfield is still in his place and does not move even though Garfield has said 'okay', 'coming', 'be right there' and 'almost ready'. Garfield starts walking when Jon has already fallen asleep.

$\begin{array}{ll}\text { Jon } & \text { : "Let's go do something." } \\ \text { Garfield } & \text { : "Okay." } \\ \text { Jon } & \text { : "Come on." } \\ \text { Garfield } & \text { : "Coming." } \\ \text { Jon } & \text { : "I'm at the door!" } \\ \text { Garfield } & \text { : "Be right there." } \\ \text { Jon } & \text { : "Let's go!" } \\ \text { Garfield } & \text { : "Almost ready." } \\ \text { Jon } & \text { : (already fallen asleep for waiting for Garfield) } \\ \text { Garfield } & \text { : "On my way." } \\ \text { Violation of maxim: Quality }\end{array}$


The maxim of quality is obviously violated so many times in the above conversation in which maxim of quality is not observed by Garfield. The responses 'coming', 'be right there', and 'almost ready' to Jon's request to do something are understood as untruthful contribution as the contribution is delivered in untruthful way and sayings. Garfield's saying is found to be in contrast to what is done by Garfield. By the time Garfield says 'Be right there', Garfield is expected to be really very close to arriving at the location of where Jon is. The phrase 'be right there' can also be understood as Garfield is on the way to go to Jon's place. In fact, the real condition is in contrast to the saying. By the time Garfield says 'almost ready', Garfield is expected to be true by telling the real and factual condition of him in the state of preparing something. In fact, Garfield is not seen to be in the middle of doing something else that requires Garfield to be in the state of not ready yet.

Violating maxim of quality many times done by Garfield is concerned as the way to deceive hearer, Jon, on purpose. In the act of deceiving someone, at least one lie can be found in the effort of making someone to believe things that are not true in the hope for gaining some personal or non-personal advantages. In the above conversation, the act of deceiving Jon is found to be done on purpose by Garfield to get personal advantage of being successful in making Jon waiting for so long. It is proven by the grin on Garfield's face when Garfield finally starts walking to Jon after knowing Jon has fallen asleep. 


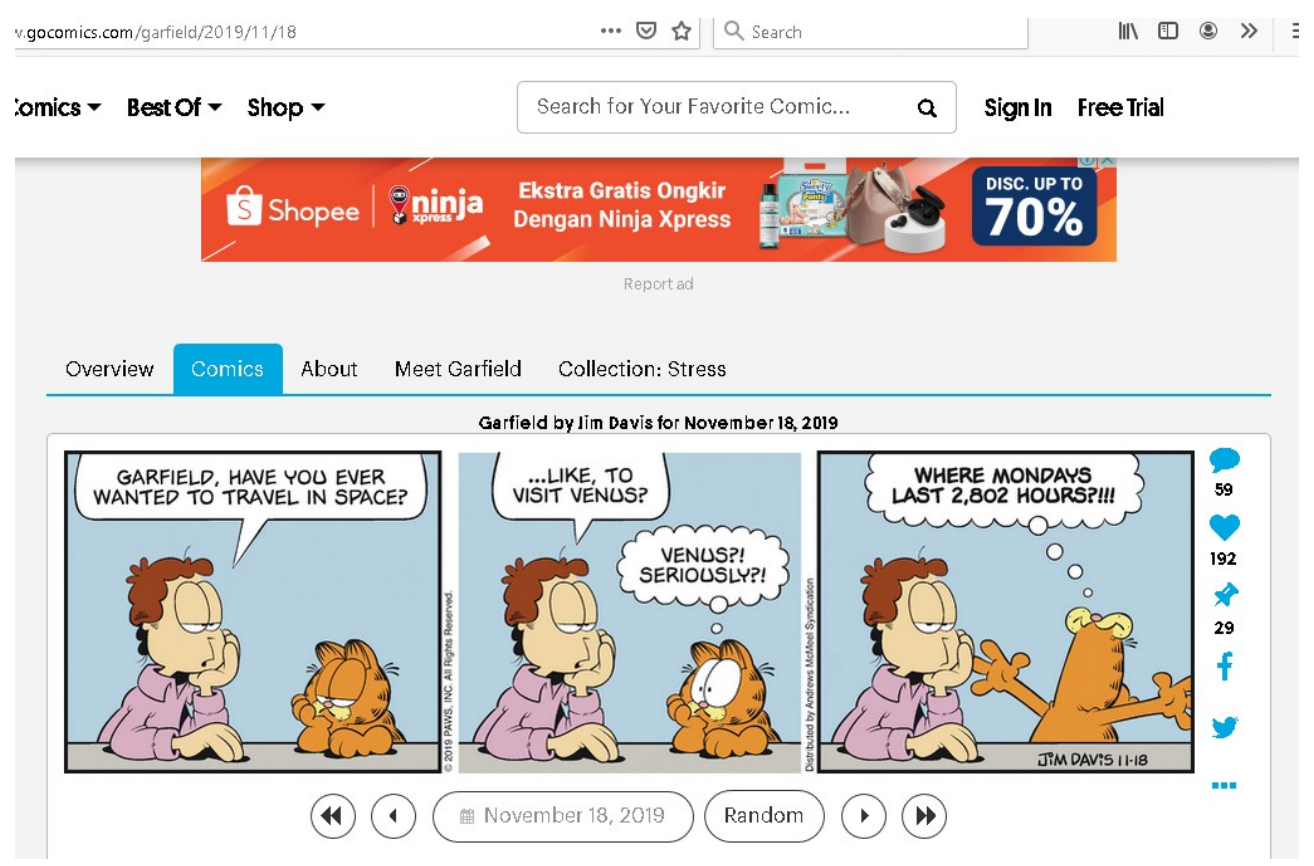

Figure 4.1.13 Garfield for November $18^{\text {th }} 2019$

\section{Datum 13 : Garfield for November $18^{\text {th }} 2019$}

Characters : Jon and Garfield

Background : Jon and Garfield are having a conversation about wanting to travel in space especially to visit Venus. Garfield is interested with the topic causing him responding by mentioning how long Mondays in Venus.

Jon : "Garfield, have you ever wanted to travel in space? Like to visit Venus?"

Garfield : (seems interested) "Venus?! Seriously?!"

Garfield : "Where Mondays last 2.802 hours?!!!"

\section{Violation of Maxim: Quantity and Manner}

Multiple violations are done by Garfield as multiple maxims that are the maxims of quantity and manner are violated at the same time. The answer "Venus?! Seriously?!" given by Garfield can be regarded as not meeting the wish or requirement for information in the terms of the quantity of information needed. The question 'Have you ever wanted to travel in space like to visit Venus?" is supposed to be responded with providing information concerning whether to travel in space like in Venus is something that Garfield has ever wanted that is expressed in terms of 'yes' or 'no' answer which is really considered as the right 
amount information (neither less or more) related to the question asked by Jon. The response can be rendered more to the state of 'Yes, I have' or 'No, I have not'

The second answer given by Garfield is regarded as not meeting the wish for information regarding the manner of what is supposed to be in delivering information. The message in the saying 'where Mondays lasts 2.802 hours?!!' cannot be understood easily as it is unclear to answer whether Garfield has ever wanted to travel in space like Venus because the saying is said to be the exclamation expression of just realizing that Monday consists of 2.802 hours, way too long if compared to Earth.

The maxims of quantity and relation are violated in order to express excitement that is proven by both Garfield's responses. Exclamation expressions in the above conversation are understood as the expressions of excitement Garfield have in a conversation about Venus. The violation of maxims is caused by the effect of Garfield being too excited about thing regarding how long Mondays in Venus. It is proven by word 'lazy' labeled to Garfield.

\section{Garfield by Jim Davis for November 28, 201}
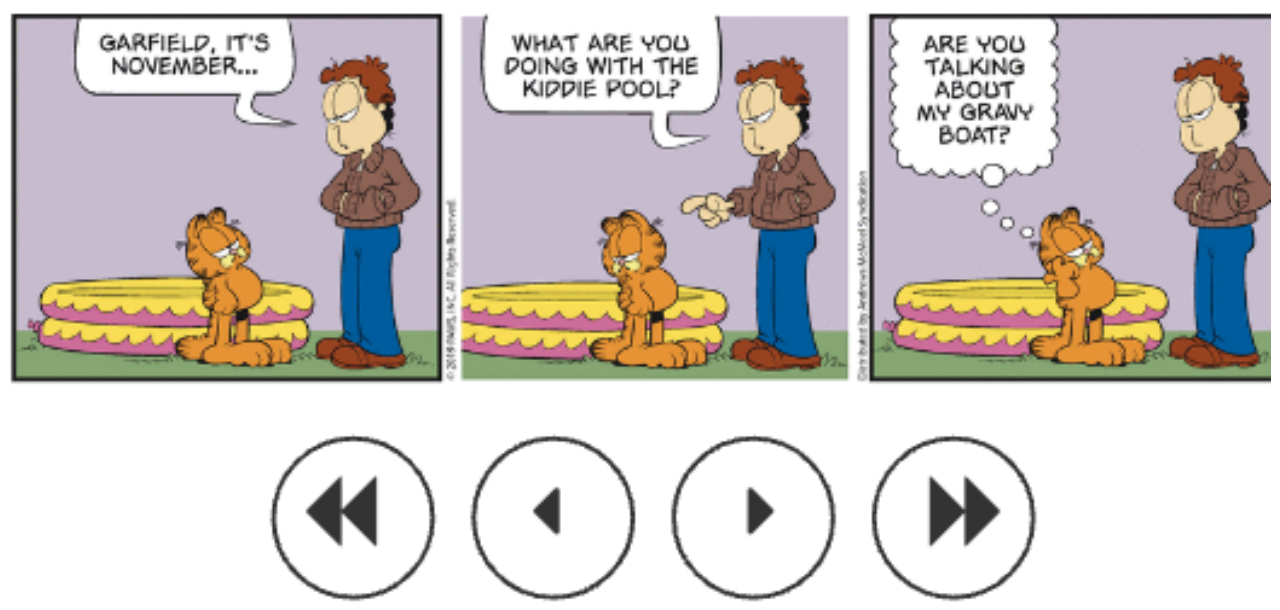

Figure 4.1.14 Garfield for November $28^{\text {th }} 2019$

Datum 14

: Garfield for November $28^{\text {th }} 2019$

Characters

: Jon and Garfield 
Background : Jon asks what Garfield does with bringing out the kiddie pool in November. Garfield answers by mentioning instead of kiddie pool, it is his gravy boat.

Jon : "Garfield, it is November. What are you doing with the kiddie pool?"

\section{Garfield "Are you talking about my gravy boat?"}

\section{Violation of Maxim: Quantity}

Maxim of quantity is violated by Garfield in the above conversation. Garfield as the participant in a conversation is required to contribute in the way of meeting the wish of the other interlocutor's need of information in the right amount in terms of obeying maxim of quantity. Jon is known to be in the need of information regarding for what the kiddie pool has something to do brought out in November in which the season is winter meaning full of snow outside. The information Garfield's saying is said to be not informative to answer the question or what is needed The answer given to the question 'what are you doing with the kiddie pool?' should be regarded about some activities as the reason of using kiddie pool. In contrast to that, the answer which is 'are you talking about gravy boat' is not said to meet the reason of using as well as not informative at all and, being so, the maxim of quantity is broken.

The violation of maxim of quantity in the above conversion is done by Garfield on purpose to save his face from using a kiddie pool. Instead of referring it as a kiddie pool, the plastic pool thing is referred by Garfield as 'gravy boat' causing maxim of quantity is violated. 


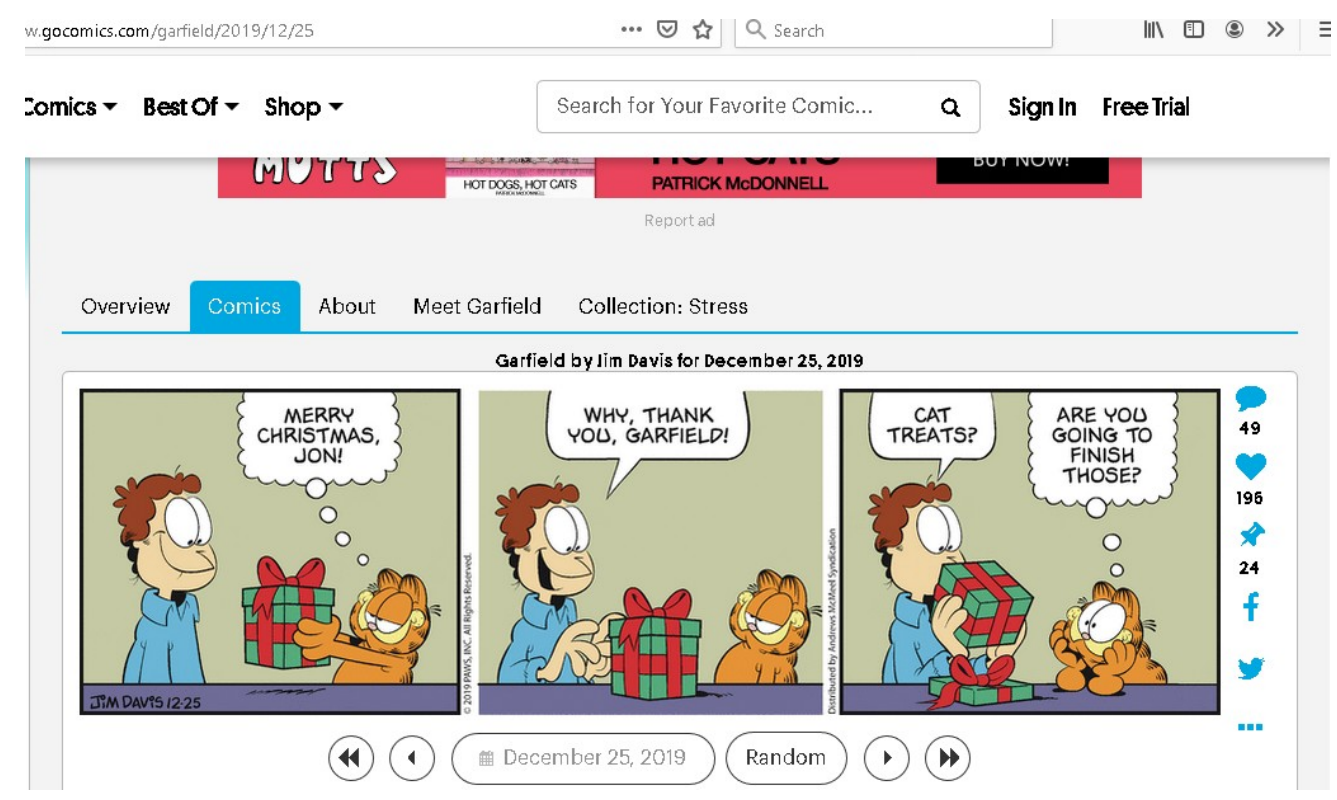

Figure 4.1.15 Garfield for December $25^{\text {th }} 2019$

\section{Datum 15 : Garfield for December $25^{\text {th }} 2019$}

Characters : Jon and Garfield

Background : Garfield gives Jon a chrismas gift and asks Jon to finish what's in there.

$\begin{array}{ll}\text { Garfield } & \text { : "Merry Christmas, Jon!" } \\ \text { Jon } & \text { : "Why, thank you, Garfield!" } \\ \text { Jon } & \text { : "Cat treats?" }\end{array}$

\section{Garfield : "Are you going to finish those?"}

\section{Violation of Maxim: Quantity}

Maxim of quantity is violated by Garfield in the above conversation. The response 'are you going to finish those' is regarded to not answer the information needed by Jon. The answer 'yes' or 'no' is required to answer the question delivered by Jon and, being so, the need of information cannot be satisfied meanwhile Garfield is expected to participant in the conversational contribution by giving informative and right amount of information. The act of Garfield being not cooperative in the form of informative contribution is said to be the proof of failing to observe maxim of quantity.

The violation of maxim of quantity done by Garfield in the above information is done in order to get the purpose of the intention faster as the 
communication is moved on faster. Knowing whether Jon is going to finish the cat treats is considered more important to Garfield than providing answer that is so obvious.

\section{CONCLUSION}

After describing and analyzing the data, conclusion is drawn as all maxims from the four Grice's conversational maxims, namely: maxim of quantity, maxim of quality, maxim of relation, and maxim of manner are not observed in terms of being violated on purpose. Fifteen comic strips are found to contain violation of maxims. Ten comic strips are said to present the violation of only one single maxim. Five comic strips are considered to demonstrate the violation of multiple maxims. Nine comic strips are found to illustrate the violation of maxim of quantity. Eight comic strips are found to illustrate the violation of maxim of quality. One comic strip is found to portray the violation of maxim of relation. Two comic strips are found to have the indication of the violation of maxim of manner. Maxim of quantity is found to be on top as the most frequent maxim violated in the comic strips with the number of nine cases followed by maxim of quality with eight cases, maxim of manner with two cases, and maxim of relation with one case. The violated of maxim of manner is the most rarely found in the comic strips.

Some ways are found to be the reasons of the violation of the maxims in Garfield comic strips by Jim Davis from July - December 2019. They are regarded as the effort to save the face, avoid doing what is asked, cheer up the hearer, convince the hearer, deceive the hearer, abuse verbally, avoid talking, satisfy the hearer, hide the truth, express excitement, and get intention faster.

\section{REFERENCE}

Arthanti, N. (2013). Violation of Grice's Maxims in the Garfield "Hangs Out" Comic: Comparison between Source Text (ST) and Target Text (TT). Semarang: Unnes Press. 
Bakhtin, M. (1986c). The Problem of Speech Genres. Speech Genres and Other Late Essays. Texas: University of Texas Press.

Bogdan, R., \& Biklen, S. K. (1982). Qualitative Research for Education: An Introduction to Theory and Methods $-3^{\text {rd }}$ Edition. Boston: Allyn and Bacon

$\begin{array}{lll}\text { Cambridge } & \text { English }\end{array}$ https://dictionary.cambridge.org/dictionary/english/conversation. Access Date 30 December 2019.

Cutting, J. (2008). Pragmatics and discourse: A resource book for students. New York: Routledges

Davis, J. Garfield. www.gocomics.com/Garfield. Access date April 2020.

Grice, H. P. (1975). Logic and Conversation. Cole and JL Morgan, Syntax and Semantics, 3. New York: Academy Press.

Haye, A., \& Larraín, A. (2011). What is an utterance? Märtsin, M., Wagoner, B., Aveling, E., Kadianaki, I., Whittaker, L. (Eds.) Dialogicality in Focus: Challenges to Theory, Method and Application Journal, 33-52. New York: Nova Science Publishers.

Levinson, S.C. (1983). Pragmatics (Cambridge Textbooks in Linguistics). Cambridge: Cambridge University Press.

American Heritage ${ }^{\circledR}$ Dictionary of the English Language (Fifth Edition). Linguistic Utterance. https://www.thefreedictionary.com/Linguistic+utterance. Access date 28 August 2020.

Miles, M.B., Huberman, A.M. \& Saldana, J. (2014). Qualitative Data Analysis: A Methods Sourcebook 3rd Edition. Thousand Oaks: SAGE Publications.

Peccei, J.S. (1999). Pragmatics. London: Routledge.

Pribadi, R.A.S. (2018). Violating Maxims as Humorous Sense in the Movie Deadpool. Language Horizon. 6(1), 50-61.

Raharja, A.U.S., \& Rosyidha, A. (2019). Maxim of Cooperative Principle Violation by Dodit Mulyanto in Stand-Up Comedy Indonesia Season 4. Journal of Pragmatic Research. 1(1), 43-61. 
Ross, Alison. (2005). The Language of Humor. New York: Taylor and Francis.

Thomas, J. (1995). Meaning in Interaction: An Introduction to Pragmatics. London: Longman.

Triyatun. (2013). Non-Observance of Grice's Maxims Found in the Death of a Salesman Drama Script by Arthur Miller: A Pragmatic Study. Unpublished thesis. Surakarta: Universitas Muhammadiyah Surakarta

Tupan, A.H., \& Natalia, H. (2008). The Multiple Violations of Conversational Maxims in Lying Done by the Characters in Some Episodes of Desperate Housewives. Kata Journal. 10(1), 63-78. Surabaya: Petra Christian University.

Xue, Z. (2017). The Non-Observance of Grice's Maxims in The Creation of Humour in A Chinese Sitcom. Dissertation. Malaysia: University Malaya.

Yule, G. (1996). Pragmatics (Oxford Introduction to Language Study Series). Oxford: Oxford University Press. 